\title{
Cisplatin-Induced Nephrotoxicity in Rats: Modulatory Role of Simvastatin and Rosuvastatin against Apoptosis and Inflammation
}

\author{
Rasha E. Mostafa*, Dalia O. Saleh, Dina F. Mansour \\ Pharmacology Department, Medical Division, National Research Centre, 33 EL Bohouth St. (former EL Tahrir St.), P.O. 12622, Dokki, Giza, Egypt.
}

\section{ARTICLE INFO \\ Article history: \\ Received on: 25/09/2017 \\ Accepted on: 07/11/2017 \\ Available online: 29/04/2018}

\section{Key words:}

Cisplatin, simvastatin, rosuvastatin, nephrotoxicity, Bax, Bcl-2, TNF- $\alpha$, IL-1 $\beta$, MPO, NF-kB, Caspase-3, Rats.

\begin{abstract}
Cisplatin use as a chemotherapeutic agent is restricted due to its nephrotoxicity. The current study investigates the possible mechanisms responsible for the nephro-protective effects of simvastatin (SIM) and rosuvastatin (RST) in cisplatin-induced nephrotoxicity in rats. Acute nephrotoxicity was induced in rats by single injection of cisplatin on the 10th day of the treatment period. Two groups received SIM and RST daily respectively, for 10 days prior to cisplatin injection. 5 days post cisplatin injection, blood samples were taken, rats were scarified and renal tissues were isolated for biochemical, immunohistochemical and histopathological assessments. Results of the study revealed that cisplatin-injected rats showed a reduction in the relative kidney weight with an elevation in the serum kidney function and renal inflammatory mediators viz. myeloperoxidase (MPO), tumor necrosis factor-alpha (TNF- $\alpha$ ),

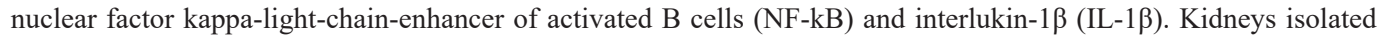
from rats injected with cisplatin showed overexpression of apoptotic markers and a decrease in the expression of the anti-apototic markers. SIM and RST significantly improved relative kidney weight, serum kidney function and restored renal tissue concentrations of inflammatory mediators. Decreased renal expression of caspases-3, Bax with increased Bcl-2 expression and improved histopathological pictures of treatment groups were observed. Our results suggest that SIM and RST have nephroprotective properties against cisplatin-induced nephrotoxicity due to their antiinflammatory and anti-apoptotic effects.
\end{abstract}

\section{INTRODUCTION}

Cisplatin (cis-diamminedichloroplatinum II) was accidentally discovered over four decades ago, and since then it has widely been used for chemotherapy (Arany and Safirstein, 2003; Wang and Lippard, 2005). Cisplatin is an essential antineoplastic agent mainly effective for the treatment of ovarian and testicular cancers (Livingston, 1989; Kuhlmann et al., 1997; Arany and Safirstein, 2003; Saleh and El-Demerdash, 2005), and many other types of cancer (Cohen and Lippard, 2001; Siddik, 2003). Two main factors generally limit cisplatin use and efficacy: acquired resistance to cisplatin and severe adverse effects in normal tissues; the latter being the major limiting factor (Wang and Lippard, 2005). These adverse include nephrotoxicity, ototoxicity,

*Corresponding Author

Rasha E. Mostafa, Pharmacology Department, Medical Division, National Research Centre, 33 EL Bohouth St. (former EL Tahrir St.), P.O. 12622, Dokki, Giza, Egypt.

E-mail:dr_rosha81@yahoo.com neurotoxicity, bone marrow suppression, anaphylaxis, nausea and vomiting (Pabla and Dong, 2008). Dose-dependent cumulative nephrotoxicity is considered the main toxicity of cisplatin, where about one-third of the patients develop nephrotoxicity after cisplatin single dose $\left(50-100 \mathrm{mg} / \mathrm{m}^{2}\right)$ (Shiraishi et al., 2000). This may be attributed to cisplatin's low molecular weight and uncharged character which allows free unbound cisplatin in the plasma to be filtered by the glomerulus, which further leads to trapping of cisplatin in the renal cortex (Launay-Vacher et al., 2008).

Cisplatin also accumulates in proximal tubules where cisplatin concentration being about five times higher than the serum concentration leading to nephrotoxicity (Kodama et al., 2014). This nephrotoxicity may be severe that it sometimes requires dose reduction or even discontinuation of treatment (Ramesh and Reeves, 2002). Dose-limiting toxicities of cisplatin have impelled the development of the non-nephrotoxic derivative carboplatin and other platinum-based preparations. However, 
cisplatin is the most commonly used chemotherapy drug and the drug of choice in many platinum-based therapy regimens (Hanigan and Devarajan, 2003). Therefore, it is essential to improve knowledge about the pathogenesis of cisplatin-induced nephrotoxicity in order to increase patient survival. The major pathophysiological mechanisms by which cisplatin induces nephrotoxicity, include renal vascular injury, proximal tubular injury, inflammation, and oxidative stress. Therefore, cisplatininduced nephrotoxicity is considered an ideal model for studying the early pathophysiological features of acute nephrotoxicity (Safirstein et al., 1986; Ozkok and Edelstein, 2014).

Several studies tested the effect of various substances to counteract the cisplatin-induced nephrotoxicity. Statins are extensively used clinically for lowering elevated serum cholesterol levels through inhibition of 3-hydroxy-3-methylglutaryl coenzyme A (HMGCoA) reductase; the catalyzing enzyme in the rate-limiting step in cholesterol synthesis (Maheshwari et al., 2013). Many studies suggested that some of the clinical benefits of statins are far beyond their cholesterol-lowering activities (Munford, 2001; Takemoto and Liao, 2001; Shishehbor et al., 2003). Statins were shown to exert the so-called pleiotropic effects, which include beneficial effects on oxidative damage, immune system, thrombosis, inflammation, and vascular \& renal functions (Davignon, 2004; Mason et al., 2004; Ray and Cannon, 2005). Statins' antioxidant effects have been thoroughly tested in many studies (Iseri et al., 2007; Dashti-Khavidaki et al., 2013; Akalin Ciftci et al., 2015). However, the exact mechanisms beyond the anti-apoptotic and anti-inflammatory effects of statins in the prevention of cisplatin-induced nephrotoxicity have not been well elucidated.

Therefore, the current study aims at scouting whether some statins namely, simvastatin (SIM) and rosuvastatin (RST) may exert significant protective effects against cisplatin-induced nephrotoxicity in rats with further emphasis on their potential antiapoptotic and anti-inflammatory properties.

\section{MATERIALS AND METHODS}

\section{Animals}

Adult male albino Wistar rats (average weight: 180-200 g) were used in the current study. Standard food pellets and tap water were provided ad libitum. Animals and food pellets were purchased from the animal house colony of the National Research Centre, Egypt. Ethical considerations in handling laboratory animals stated by the ethics committee of National Research Centre were followed throughout the study period.

\section{Preparation of drugs}

Cisplatin vials (Cisplatin ${ }^{\circledR}$, Bristol Mayers Co., USA) were used in the current study. Simvastatin (Zocor ${ }^{\circledR}$, MSD, USA) and rosuvastatin (Crestor $\AA$, AstraZeneca, USA) were orally administered in the current study.

All other chemicals were of the highest commercial grade available.

\section{Experimental design}

Forty rats were weighed and randomly allocated into four groups (10 rats each). Rats of the group one received i.p. injections of saline and served as a normal group. Acute nephrotoxicity was induced in rats in the other three groups using cisplatin in a single nephrotoxic dose of $7 \mathrm{mg} / \mathrm{kg}$ on the 10th day of treatment of the treatment period according to the method described previously (Jones et al., 1991; Saleh and El-Demerdash, 2005). Group two received only saline for 10 days and served as cisplatin control group. Groups three and four received simvastatin (SIM; $10 \mathrm{mg}$ / $\mathrm{kg}$, p.o.) and rosuvastatin (RST; $10 \mathrm{mg} / \mathrm{kg}$, p.o.) on daily basis for 10 days, respectively. All animals were weighed and sacrificed 5 days post-Cisplatin administration; blood samples were taken, renal tissues were isolated and weighed. The sera and kidneys were obtained for the biochemical, immunohistochemical and histopathological investigations.

Scarification of animals was carried out by cervical dislocation under light ether anesthesia. The two kidneys from each rat were instantly extracted and rinsed with PBS (phosphate buffer saline) to remove any remaining blood. Whole kidney weight was determined. Homogenization of kidney tissue was performed using MPW-120 homogenizer (Med instruments, Poland) in PBS. The obtained 20\% homogenates were stored for 24 hours at $-20^{\circ} \mathrm{C}$ and then they were centrifuged for 5 minutes at $5000 \mathrm{x}$ g using a cooling centrifuge (Sigma and laborzentrifugen, $2 \mathrm{k} 15$, Germany). The supernatant was then obtained immediately.

\section{Biochemical analysis}

Sera were used for determination of serum creatinine, urea, and uric acid levels, using commercially available diagnostic kits (Biodiagnostic, Egypt).

Tissue homogenates were assayed for myeloperoxidase (MPO) (hycult Biotech, Netherlands), Tumor necrosis factoralpha (TNF- $\alpha$ ) (RayBiotech, USA), nuclear factor-kappa B (NF$\mathrm{kB}$ ), and interleukin-1 $\beta$ (IL-1 $\beta$ ) (R\&D Systems, USA) according to the supplied manufacturer's instructions.

\section{Immunohistochemical examination}

Immunostaining of anti-caspase-3 antibodies was done by streptoavidin-biotin. Four-micrometer-thick sections were deparaffinized and incubated with freshly prepared $0.3 \%$ hydrogen peroxide in methanol. The sections were then incubated with anti-caspase-3 antibody as the primer antibody at a 1:100 dilution, followed by counterstaining with hematoxylin and eosin (H\&E). Light microscopy examination was performed thereafter. Negative controls were prepared by replacing normal rat serum for each primary antibody (Salama et al., 2016).

One-mm-thick semi-thin sections were deparaffinized and incubated with freshly prepared $0.3 \%$ hydrogen peroxide in methanol. Sections were incubated with either anti-Bcl-2 antibodies $(1: 200)$ or anti-Bax antibodies $(5 \mathrm{mg} / \mathrm{ml})$ for the localization of $\mathrm{Bcl}-2$ and $\mathrm{Bax}$, respectively. Thereafter, the sections were counterstained with $\mathrm{H} \& \mathrm{E}$ and examined with a light microscope (Song et al., 2012).

\section{Histopathological examination}

Kidney tissues obtained from all groups were fixed in $10 \%$ formalin followed by washing, dehydration, and fixation in paraffin. Five-mm-thick sections were stained with $\mathrm{H} \& \mathrm{E}$ and examined using a light microscope (Carleton et al., 1967). Random high microscopic fields were examined for evaluation 
of the histopathological lesions using binocular Olympus CX31 microscope (Bancroft et al., 1996).

\section{Statistical analysis}

All the values are presented as means \pm standard error of the means (SE). One way analysis of variance (ANOVA) was used to compare between different groups, followed by Tukey's multiple comparison post hoc test. $p<0.05$ was considered the cutoff value of significance. GraphPad prism ${ }^{\circledR}$ software was used to perform these statistical tests.

\section{RESULTS}

\section{Effects of SIM and RST on relative kidney weight}

Initial and final body weights of rats of different groups were recorded and all groups showed a non-statistically significant change in their initial and final body weights. Cisplatin administration ( $7 \mathrm{mg} / \mathrm{kg}$, i.p) caused a significant decrease in kidney weight to $74 \%$ when compared to normal group. Simvastatin (10 mg/kg/day; p.o.) administration caused a significant increase in kidney weight to $129 \%$ while RST (10 $\mathrm{mg} / \mathrm{kg} /$ day; p.o.) administration caused a non-significant increase in kidney weight to $125 \%$ when compared to cisplatin control group. Moreover, Cisplatin administration ( $7 \mathrm{mg} / \mathrm{kg}$, i.p) caused a significant decrease in kidney weight/final body weight ratio $\%$ when compared to normal group. SIM (10 mg/kg/day; p.o.) and RST (10 mg/kg/day; p.o.) administration significantly increased and almost normalized kidney weight/final body weight ratio $\%$ as compared to cisplatin control group (Table 1).

Table 1: Effects of SIM and RST on the change in body weight, kidney weight and relative kidney weight in cisplatin-induced acute nephrotoxicity in rats.

\begin{tabular}{cccc}
\hline Groups & $\begin{array}{c}\text { Percent change in body } \\
\text { weight }(\%)\end{array}$ & $\begin{array}{c}\text { Kidney weight } \\
\text { (g) }\end{array}$ & $\begin{array}{c}\text { Relative kidney } \\
\text { weight }(\mathbf{g} / \mathbf{1 0 0} \\
\text { body weight })\end{array}$ \\
\hline Normal & $94 \% \pm 0.03$ & $1.17 \pm 0.04$ & $0.99^{\mathrm{b}} \pm 0.01$ \\
$\begin{array}{c}\text { Cisplatin control } \\
(7 \mathrm{mg} / \mathrm{kg}, \mathrm{i} . \mathrm{p})\end{array}$ & $94 \% \pm 0.02$ & $0.87^{\mathrm{a}} \pm 0.05$ & $0.64^{\mathrm{a}} \pm 0.02$ \\
$\begin{array}{c}\text { Cisplatin }+ \text { SIM } \\
(10 \mathrm{mg} / \mathrm{kg}, \text { p.o. })\end{array}$ & $93 \% \pm 0.04$ & $1.12^{\mathrm{b}} \pm 0.03$ & $0.96^{\mathrm{b}} \pm 0.04$ \\
$\begin{array}{c}\text { Cisplatin }+ \text { RST } \\
(10 \mathrm{mg} / \mathrm{kg}, \text { p.o. })\end{array}$ & $85 \% \pm 0.03$ & $1.09 \pm 0.12$ & $0.94^{\mathrm{b}} \pm 0.02$ \\
\hline
\end{tabular}

Rats of the normal group received i.p. injections of saline. Group 2 received only saline p.o. for 15 days and served as cisplatin control group. Groups 3 and 4 received simvastatin (SIM; $10 \mathrm{mg} / \mathrm{kg}$, p.o.) and rosuvastatin (RST; $10 \mathrm{mg}$ / $\mathrm{kg}$, p.o.) respectively for 15 days. Acute nephrotoxicity was induced in groups 2,3 and 4 by a single injection of cisplatin $(7 \mathrm{mg} / \mathrm{kg}$, i.p) on the 10 th day of treatment. All animals were sacrificed 5 days after Cisplatin injection. Initial and final body weights, as well as kidney weight, were recorded.

Data is presented as mean $\pm \mathrm{SE}(\mathrm{n}=10)$.

aSignificantly different from Normal group at $p<0.05$ (Tukey's post hoc test) bSignificantly different from Cisplatin control group at $p<0.05$ (Tukey's post hoc test).

\section{Biochemical parameters}

\section{Effects of SIM and RST on serum kidney functions}

Cisplatin administration $(7 \mathrm{mg} / \mathrm{kg}$, i.p) resulted in a significant elevation in serum concentration of creatinine, urea, and uric acid to $150 \%, 179 \%$, and $174 \%$ respectively when compared to normal group. SIM (10 mg/kg/day; p.o.) administration showed decrease in serum concentration of creatinine, urea, and uric acid to $141 \%, 87 \%$, and $97 \%$ respectively and this effect was similar to control group, while RST (10 mg/kg/day; p.o.) administration resulted in significant decrease in serum concentration of creatinine, urea, and uric acid to $57 \%, 68 \%$, and $73 \%$ respectively as compared to cisplatin control group (Table 2).

Table 2: Effects of SIM and RST on serum kidney functions in cisplatin-induced acute nephrotoxicity in rats.

\begin{tabular}{cccc}
\hline Groups & $\begin{array}{c}\text { Creatinine } \\
(\mathbf{m g} / \mathbf{d L})\end{array}$ & $\begin{array}{c}\text { Urea } \\
(\mathbf{m g} / \mathbf{d L})\end{array}$ & $\begin{array}{c}\text { Uric acid } \\
(\mathbf{m g} / \mathbf{d L})\end{array}$ \\
\hline Normal & $21.81 \pm 1.65$ & $42.81 \pm 5.12$ & $0.98 \pm 0.11$ \\
$\begin{array}{c}\text { Cisplatin control } \\
(7 \mathrm{mg} / \mathrm{kg}, \mathrm{i} . \mathrm{p})\end{array}$ & $32.62^{\mathrm{a}} \pm 1.32$ & $76.63^{\mathrm{a}} \pm 3.61$ & $1.71^{\mathrm{a}} \pm 0.14$ \\
$\begin{array}{l}\text { Cisplatin }+ \text { SIM } \\
(10 \mathrm{mg} / \mathrm{kg}, \text { p.o. })\end{array}$ & $26.06 \pm 1.92$ & $66.50^{\mathrm{a}} \pm 1.33$ & $1.66^{\mathrm{a}} \pm 0.14$ \\
$\begin{array}{l}\text { Cisplatin }+ \text { RST } \\
(10 \mathrm{mg} / \mathrm{kg}, \text { p.o. })\end{array}$ & $18.47^{\mathrm{b}} \pm 2.04$ & $52.45^{\mathrm{b}, \mathrm{c}} \pm 2.96$ & $1.24^{\mathrm{b}} \pm 0.08$ \\
\hline
\end{tabular}

Rats of the normal group received i.p. injections of saline. Group 2 received only saline p.o. for 15 days and served as cisplatin control group. Groups 3 and 4 received simvastatin (SIM; $10 \mathrm{mg} / \mathrm{kg}$, p.o.) and rosuvastatin (RST; $10 \mathrm{mg}$ / $\mathrm{kg}$, p.o.) respectively for 15 days. Acute nephrotoxicity was induced in groups 2,3 and 4 by a single injection of cisplatin $(7 \mathrm{mg} / \mathrm{kg}$, i.p) on the 10 th day of treatment. All animals were sacrificed 5 days after Cisplatin injection. Blood samples were collected and sera were separated.

Data is presented as mean $\pm \operatorname{SE}(n=10)$.

a Significantly different from Normal group at $p<0.05$ (Tukey's post hoc test). bignificantly different from Cisplatin control group at $p<0.05$ (Tukey's post hoc test).

'Significantly different from Cisplatin + SIM group at $p<0.05$ (Tukey's post hoc test).

\section{Effects of SIM and RST on renal inflammatory markers and cytokines}

Cisplatin administration ( $7 \mathrm{mg} / \mathrm{kg}$, i.p) resulted in a significant abrupt elevation in tissue concentration of MPO, TNF- $\alpha$, NF-kB, and IL- $1 \beta$ to $472 \%, 695 \%, 546 \%$ and $617 \%$ respectively when compared to normal group. SIM $(10 \mathrm{mg} /$ $\mathrm{kg}$ /day; p.o.) administration resulted in significant decline in tissue concentration of MPO, TNF- $\alpha$, NF-kB and IL- $1 \beta$ to $37 \%$, $33 \%, 39 \%$ and $34 \%$ respectively. Moreover, RST $(10 \mathrm{mg} / \mathrm{kg} /$ day; p.o.) administration resulted in significant decline in tissue concentration of MPO, TNF- $\alpha$, NF-kB, and IL- $1 \beta$ to $54 \%, 42 \%$, $51 \%$ and $58 \%$ respectively as compared to cisplatin control group. The effect of RST was significantly better than that of SIM in all the aforementioned tissue parameters (Table 3).

\section{Immunohistochemical determination of Caspase-3, Bcl-2, and Bax in kidney tissue}

Immunohistochemical determination of caspase-3 showed negative immunostaining in normal rats and mild immunostaining in of the tubular lining epithelium in cortex and medulla of cisplatin control group. Administration of either simvastatin or rosuvastatin resulted in negative caspase-3 immunostaining of the tubular lining epithelium in cortex and medulla (Figure 1).

Immunohistochemical determination of Bcl-2 showed mild immunostaining in normal and cisplatin control groups. 
Administration of either simvastatin or rosuvastatin resulted in severe Bcl-2 immunostaining of the tubular lining epithelium in cortex and medulla; signifying resolving of apoptosis (Figure 2).

Table 3: Effects of SIM and RST on renal inflammatory markers and cytokines in cisplatin-induced acute nephrotoxicity in rats.

\begin{tabular}{|c|c|c|c|c|}
\hline Groups & $\begin{array}{l}\text { MPO } \\
(\mathrm{U} / \mathrm{g})\end{array}$ & $\begin{array}{c}\text { TNF- } \alpha \\
\text { (pg/g tissue) }\end{array}$ & $\begin{array}{c}\text { NF-kB } \\
\text { (ng/g tissue) }\end{array}$ & $\begin{array}{c}\text { IL-1及 } \\
\text { (Pg/g tissue) }\end{array}$ \\
\hline Normal & $1.10 \pm 0.01$ & $4.25 \pm 0.25$ & $0.69 \pm 0.06$ & $5.30 \pm 0.27$ \\
\hline $\begin{array}{l}\text { Cisplatin control } \\
(7 \mathrm{mg} / \mathrm{kg}, \text { i.p })\end{array}$ & $5.21^{\mathrm{a}} \pm 0.26$ & $29.53^{\mathrm{a}} \pm 1.39$ & $3.76^{a} \pm 0.06$ & $32.73^{\mathrm{a}} \pm 2.14$ \\
\hline $\begin{array}{l}\text { Cisplatin + SIM } \\
(10 \mathrm{mg} / \mathrm{kg}, \text { p.o. })\end{array}$ & $1.90^{\mathrm{a}, \mathrm{b}} \pm 0.07$ & $9.85^{\mathrm{a}, \mathrm{b}} \pm 0.30$ & $1.46^{\mathrm{a}, \mathrm{b}} \pm 0.03$ & $11.13^{\mathrm{a}, \mathrm{b}} \pm 0.44$ \\
\hline $\begin{array}{l}\text { Cisplatin + RST } \\
(10 \mathrm{mg} / \mathrm{kg}, \text { p.o. })\end{array}$ & $2.79^{a, b, c} \pm 0.08$ & $12.38^{\mathrm{a}, \mathrm{b}, \mathrm{c}} \pm 0.69$ & $1.92^{\mathrm{a}, \mathrm{b}, \mathrm{c}} \pm 0.48$ & $19.13^{\mathrm{a}, \mathrm{b}, \mathrm{c}} \pm 0.48$ \\
\hline
\end{tabular}

Rats of the normal group received s.c. injections of saline. Group 2 received only saline p.o. for 15 days and served as cisplatin control group. Groups 3 and 4 received simvastatin (SIM; $10 \mathrm{mg} / \mathrm{kg}$, p.o.) and rosuvastatin (RST; $10 \mathrm{mg} / \mathrm{kg}$, p.o.) respectively for 15 days. Acute nephrotoxicity was induced in groups 2, 3 and 4 by a single injection of cisplatin $(7 \mathrm{mg} / \mathrm{kg}$, i.p.) on the 10th day of treatment. All animals were sacrificed 5 days after Cisplatin injection. The kidneys were removed, homogenized and the homogenate was obtained.

Data is presented as mean $\pm \operatorname{SE}(n=10)$.

aSignificantly different from Normal group at $p<0.05$ (Tukey's post hoc test).

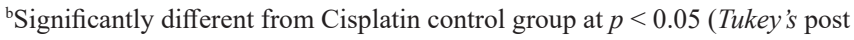
hoc test).

'Significantly different from Cisplatin + SIM group at $p<0.05$ (Tukey's post hoc test).

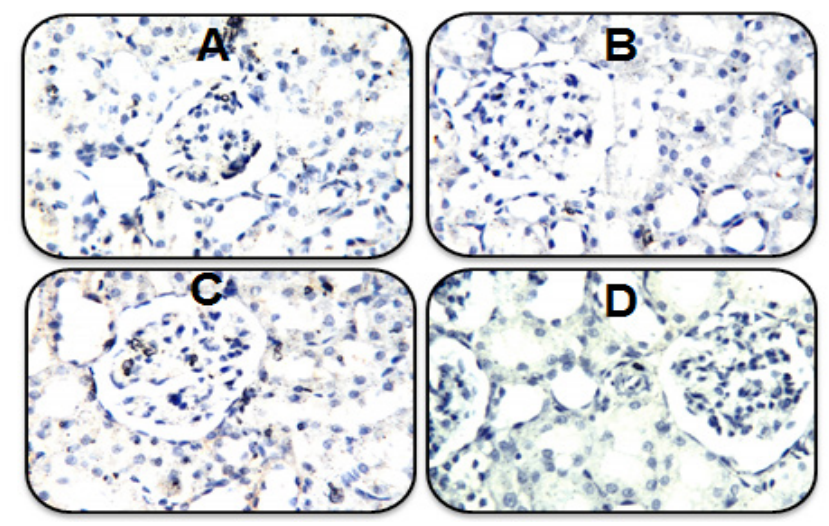

Fig. 1: A. Photomicrograph of kidney sections prepared from a normal rat showing negative caspase-3 immunostaining of the tubular lining epithelium in cortex and medulla (Caspase-3 immunohistochemistry, H\&E X 80). B. Photomicrograph of kidney sections prepared from a cisplatin control rat showing mild caspase-3 immunostaining of the tubular lining epithelium in cortex and medulla (Caspase-3 immunohistochemistry, H\&E X 80). C. Photomicrograph of kidney sections prepared from a rat treated with SIM $(10 \mathrm{mg} / \mathrm{kg}$, p.o.) for 15 days and cisplatin $(7 \mathrm{mg} / \mathrm{kg}$, i.p.) on the 10 th day of treatment showing negative caspase-3 immunostaining of the tubular lining epithelium in cortex and medulla (Caspase-3 immunohistochemistry, H\&E X 80). D. Photomicrograph of kidney sections prepared from a rat treated with RST (10 mg/kg, p.o.) for 15 days and cisplatin ( $7 \mathrm{mg} / \mathrm{kg}$, i.p.) on the 10th day of treatment showing negative caspase-3 immunostaining of the tubular lining epithelium in cortex and medulla (Caspase-3 immunohistochemistry, H\&E X 80).

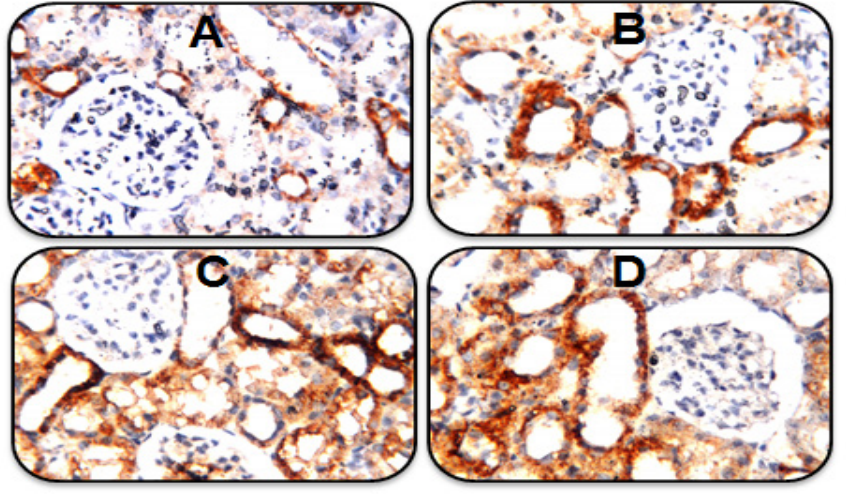

Fig. 2: A. Photomicrograph of kidney sections prepared from a normal rat showing mild Bcl-2 immunostaining of the tubular lining epithelium in cortex and medulla (Bcl-2 immunohistochemistry, H\&E X 80). B. Photomicrograph of kidney sections prepared from a cisplatin control rat showing mild Bcl-2 immunostaining of the tubular lining epithelium in cortex and medulla (Bcl2 immunohistochemistry, H\&E X 80). C. Photomicrograph of kidney sections prepared from a rat treated with SIM $(10 \mathrm{mg} / \mathrm{kg}$, p.o.) for 15 days and cisplatin $(7 \mathrm{mg} / \mathrm{kg}$, i.p.) on the 10th day of treatment showing severe Bcl-2 immunostaining of the tubular lining epithelium in cortex and medulla (Bcl-2 immunohistochemistry, H\&E X 80). D. Photomicrograph of kidney sections prepared from a rat treated with RST $(10 \mathrm{mg} / \mathrm{kg}$, p.o.) for 15 days and cisplatin $(7 \mathrm{mg} / \mathrm{kg}$, i.p.) on the 10th day of treatment showing severe Bcl-2 immunostaining of the tubular lining epithelium in cortex and medulla (Bcl-2 immunohistochemistry, $H \& E$ X 80).

Immunohistochemical determination of Bax showed normal immunostaining in normal rats and severe immunostaining in cisplatin control group. Administration of simvastatin resulted in negative Bcl-2 immunostaining while administration of rosuvastatin resulted in moderate immunostaining of the tubular lining epithelium in cortex and medulla (Figure 3 ).

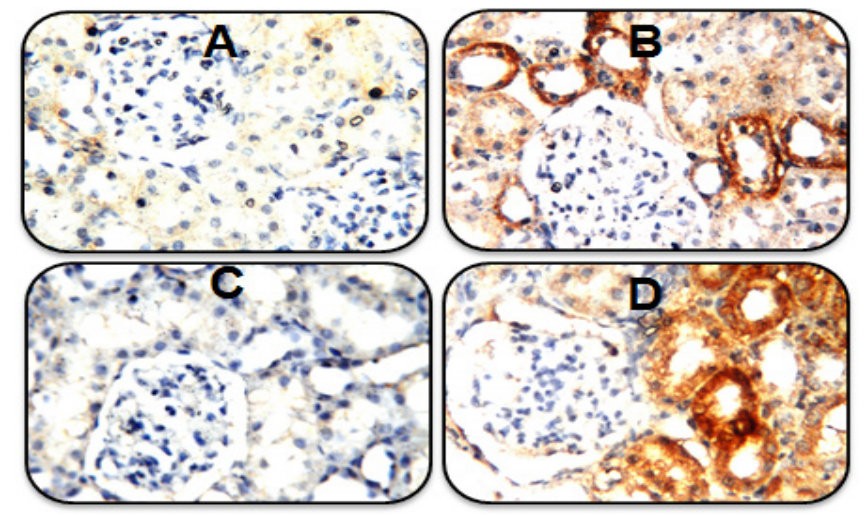

Fig. 3: A. Photomicrograph of kidney sections prepared from a normal rat showing negative Bax immunostaining of the tubular lining epithelium in cortex and medulla (Bax immunohistochemistry, H\&E X 80). B. Photomicrograph of kidney sections prepared from a cisplatin control rat showing severe Bax immunostaining of the tubular lining epithelium in cortex and medulla (Bax immunohistochemistry, H\&E X 80). C. Photomicrograph of kidney sections prepared from a rat treated with SIM $(10 \mathrm{mg} / \mathrm{kg}$, p.o.) for 15 days and cisplatin $(7 \mathrm{mg} / \mathrm{kg}$, i.p.) on the 10th day of treatment showing negative Bax immunostaining of the tubular lining epithelium in cortex and medulla (Bax immunohistochemistry, H\&E X 80). D. Photomicrograph of kidney sections prepared from a rat treated with RST $(10 \mathrm{mg} / \mathrm{kg}$, p.o.) for 15 days and cisplatin $(7 \mathrm{mg} / \mathrm{kg}$, i.p.) on the 10th day of treatment showing moderate Bax immunostaining of the tubular lining epithelium in cortex and medulla (Bax immunohistochemistry, H\&E X 80). 


\section{Histopathological examination of renal tissue}

Histopathological examination of renal tissue from normal rat showed normal structure of the glomeruli and tubules. Cisplatin control rats showed coagulative necrosis and severe degenerative changes in the tubular lining epithelium. Administration of either simvastatin or rosuvastatin resulted in improvement of the overall histopathological picture of the kidneys (Figure 4).

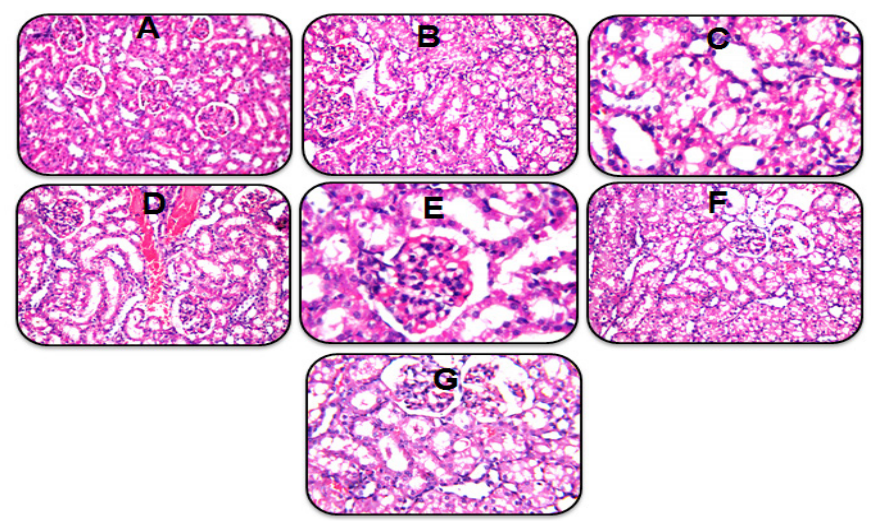

Fig. 4: A. Photomicrograph of kidney sections prepared from a normal rat showing no histopathological alteration and the normal histological structure of the glomeruli and tubules at the cortex were recorded (H\&E X 40). B. Photomicrograph of kidney sections prepared from a cisplatin control rat showing coagulative necrosis and severe degenerative changes in the tubular lining epithelium (H\&E X 40). C. Magnification of figure 4B showed swelling in the endothelial cells lining the congested glomerular tufts (H\&E X 80). D. Photomicrograph of kidney sections prepared from a rat treated with SIM (10 $\mathrm{mg} / \mathrm{kg}$, p.o.) for 15 days and cisplatin $(7 \mathrm{mg} / \mathrm{kg}$, i.p.) on the 10 th day of treatment showing mild congestion in the glomeruli and the intertubular blood vessels at the cortex (H\&E X 40). E. Magnification of figure 4D showed improvement of the overall histopathological picture of the kidneys in this group (H\&E X 80). F. Photomicrograph of kidney sections prepared from a rat treated with RST (10 mg/kg, p.o.) for 15 days and cisplatin ( $7 \mathrm{mg} / \mathrm{kg}$, i.p.) on the 10 th day of treatment showing mild degenerative changes in the lining epithelium of the tubules. (H\&E X 40). G. Magnification of figure 4F showed mild improvement of the overall histopathological picture of the kidneys in this group (H\&E X 80).

\section{DISCUSSION}

Nephrotoxicity is the key limitation of cisplatin-based chemotherapy protocols. Direct toxicity of cisplatin through oxidative stress (Lieberthal et al., 1996; Baliga et al., 1998), inflammation and cytokine activity has been implicated in the pathogenesis of cisplatin-induced nephrotoxicity (Deng et al., 2001; Ramesh and Reeves, 2002; Ramesh and Reeves, 2004). The recent observation that 3-Hydroxy-3-methyl-gutaryl coenzyme A (HMG-CoA) reductase inhibitors or statins, the most effective group of lipid-lowering drugs, possess more clinical benefits related to anti-inflammatory properties, immunomodulatory effects (Blanco-Colio et al., 2003) and recently anti-oxidative mechanisms (Haendeler et al., 2004). However, the mechanism by which statins could protect against cisplatin-induced nephrotoxicity is not well defined.

In the present study, cisplatin administration resulted in a significant decrease in kidney weight and kidney weight/body weight ratio compared to normal rats. Significant nephrotoxicity was observed after cisplatin administration as detected by elevations in serum creatinine, urea, and uric acid. In accordance, others reported increases in serum creatinine, and blood urea nitrogen (Saleh and El-Demerdash, 2005; Shimeda et al., 2005; Palipoch et al., 2014). Regardless their lipid-lowering activities, some statins possess favorable effects on the cardiovascular system, immune system, oxidative damage, immune system, and vascular \& renal functions (Davignon, 2004; Mason et al., 2004; Ray and Cannon, 2005; Akalin Ciftci et al., 2015). Previous data demonstrated the protective actions of statins on oxidative stress in the kidney and other different body organs (Iseri et al., 2007; An et al., 2011; Khoshnoud et al., 2011; Dashti-Khavidaki et al., 2013). In the present study, administration of SIM $(10 \mathrm{mg} / \mathrm{kg})$ and RST $(10 \mathrm{mg} / \mathrm{kg})$ resulted in a significant increase in kidney weight and kidney weight/final body weight ratio when compared to cisplatin control group. Moreover, renal dysfunction was improved by SIM and RST administration.

Cisplatin is metabolically converted to a more potent toxin that causes DNA injury, mitochondrial DNA and respiration damage with activation of apoptotic pathways, and initiation of inflammatory responses (Miller et al., 2010). Significant elevation of myeloperoxidase (MPO) level in cisplatin nephrotoxicity has been observed along with pro-inflammatory cytokines; TNF- $\alpha$, and IL-1 $\beta$ indicative of provoked inflammatory response as reported earlier (Amirshahrokhi and Khalili, 2015). Myeloperoxidase (MPO) was found to exert a primary role in chronic inflammation (Podrez et al., 2000) as well as in oxidative damage in various body organs (Vita et al., 2004) and demonstrates an essential mechanistic link between oxidation and inflammation (Madhusudhana Rao et al., 2011).

The oxidative stress exerted by cisplatin activates the transcription factor-nuclear factor kappa B (NF-kB) - thus promoting the production of pro-inflammatory cytokines, such as TNF- $\alpha$ (Ramesh and Reeves, 2002). Our data reported further increase in the transcription factor NF-kB when compared to normal group. Moreover, NF-kB plays major roles in oxidative stress, inflammation and regulation of gene coding for cytokines and apoptosis, accordingly, kidney tissue pro-inflammatory cytokines TNF- $\alpha$ \& IL-1 $\beta$ and kidney tissue NF-kB were elevated significantly after cisplatin administration in mice (Pan et al., 2015). Also in line with the current data; Liu et al., (2016) stated that the main mechanism for cisplatin-induced nephrotoxicity was through tubular epithelial cell apoptosis where caspases-3 was highly expressed (Liu et al., 2016). Caspase-3 immunohistochemistry reported mild reactivity in cisplatintreated group compared to normal counterparts. Being the most important mechanism involved in proximal tubular injury (Wei et al., 2007), apoptosis is induced through stimulation of death receptors such TNF- $\alpha$ leading to activation of different caspases (Strasser et al., 2000).

The activation of the previous apoptotic pathway strongly implicate the mitochondrial apoptotic pathways in cisplatininduced tubular cell death which was evident by overexpression of Bax while under expression of Bcl-2 in the tubular lining epithelium in cortex and medulla by immunohistochemistry in cisplatin-exposed kidneys. Meanwhile, cisplatin administration leads to translocation of Bax in mitochondria (Lee et al., 2001) and subsequently, overexpression of caspases 3,8 and 9 occur as prompt as 12 hours post cisplatin (Kaushal et al., 2001). Upon activation of Bax, a shift between the equilibrium of the 
pro- and antiapoptotic Bcl-2 proteins directs to the pro-apoptotic pathways, specifically caspase-dependent one (Pabla and Dong, 2008) explaining the reason behind less expression of Bcl-2 after cisplatin administration. In accordance, treatment of cultured tubular cells with cisplatin led to reduction and degradation of the anti-apoptotic proteins including Bcl-2, Bcl-XL, and Mcl-1 (Jiang et al., 2006). While pro-apoptotic proteins viz. Bax and Bak are not changed (Yang et al., 2007). Therefore, the ratio between Bax and Bcl-2 has been reported to be elevated during cisplatin nephrotoxicity (Sheikh-Hamad et al., 2004). This shift in apoptotic gene expression to enhance the activation of Bax is greatly believed to trigger mitochondrial injury and apoptosis. Recent studies showed that cisplatin administration markedly enhanced Bax expression leading to apoptosis and nephrotoxicity in mice (Wei et al., 2007) and decreased Bcl-2 expression level in mice kidney tissues (Tilyek et al., 2016).

Acute nephrotoxicity was further proved by the histopathological variations including swelling and vacuolation of the lining endothelium of the glomerulus as well as tubular degeneration and dilation of the blood vessels with focal minute haemorrhage in the cortical section. Severe tubular swelling, necrosis, and degeneration in glomeruli, proximal, and distal tubules were also apparent in the current investigation. Iseri et al. (2007) stated that cisplatin produced severe nephrotoxicity manifested by elevation of blood urea nitrogen (BUN) and serum creatinine as well as a decrement in creatinine clearance value, elevation in kidney tissue MPO concentration along with significant histopathological changes (Ozkok and Edelstein, 2014).

Administration of SIM and RST markedly protected against cisplatin-induced elevation in renal tissue MPO, TNF- $\alpha$, IL-1 $\beta$, NF-kB and caspase-3, suggesting significant protection against cisplatin-induced nephro-inflammation and apoptosis. Our data is in agreement with Iseri et al. (2007) who demonstrated that the beneficial actions of SIM against cisplatin-induced kidney and liver damage in rats were through prevention of lipid peroxidation, tissue fibrosis, and conservation of antioxidant glutathione. Similarly, SIM and RST protective effects against cisplatininduced acute kidney injury were mainly via improvement of lipid peroxidation, renal function as well as their lipid-lowering effects (Maheshwari et al., 2013). Further, pravastatin protected against cisplatin-induced kidney oxidative stress damage and attenuated apoptosis manifested by changes in p53 apoptotic cells in renal proximal tubules (Fujieda et al., 2011), and improved serum creatinine, BUN, kidney tissue GSH, MDA, SOD and catalase with decreased histopathological damage induced by cisplatin in mice (An et al., 2011).

Recently, SIM ameliorated gentamicin-induced increase in serum creatinine and proximal tubular cell necrosis in a dosedependent manner (Jabbari et al., 2011), while statins reduced intracellular gentamicin concentration (Antoine et al., 2010). Moreover, RST decreased cyclosporine-induced nephrotoxicity, tubular apoptosis, atrophy and fibrosis by decreasing expression of Bax/Bcl-2 ratio (Nam et al., 2012).

The effect of statins on the expression levels of the proand anti-apoptotic Bcl-2 family of proteins has been proposed as one of the mechanisms involved in different protective properties of statins. Our findings revealed that SIM and RST treatment in cisplatin nephrotoxicity greatly affected the expression levels of Bax and Bcl-2 towards the pathways that reduce apoptosis and cell death by decreasing Bax and increasing Bcl-2 immunostaining in rat tubular cells. Of note, SIM reported negative Bax while severe Bcl-2 immunostaining in rat renal tissues, meanwhile, RST showed moderate Bax but severe Bcl-2 expression. In accordance, mice receiving oral SIM $(120 \mu \mathrm{mol} / \mathrm{kg}$ for 21 days $)$ reported a significant increase in brain Bcl-2 gene expression (JohnsonAnuna et al., 2005).

Previous studies on guinea pigs demonstrated that SIM increased Bcl-2 protein levels whilst Bax protein levels were significantly reduced, with further neuroprotection of dissociated brain cells when challenged with sodium nitroprusside and the Bcl-2 protein inhibitor (Franke et al., 2007). Further, SIM (2.4 $\mu \mathrm{mol} / \mathrm{kg}$ i.p./day, 2 or 8 weeks) exhibited neuroprotective properties in a rat model of Huntington's disease (Patassini et al., 2008). Other studies demonstrated that statins increased Bcl-2 abundance and decreased apoptosis in vivo (Malik et al., 2011; Qin et al., 2012; Rajtik et al., 2012).

Several in vitro studies support the notion that statins increase Bcl-2 and reduce apoptosis, providing neuroprotective activity through increased Bcl-2 mRNA and protein levels upon SIM treatment of mouse primary neurons challenged with oligomeric amyloid $\beta$-protein (Johnson-Anuna et al., 2007). Moreover, fluvastatin (0.01-0.1 $\mu \mathrm{M})$ increased Bcl-2 mRNA expression and protein levels in human vascular endothelial cells challenged with $\mathrm{H}_{2} \mathrm{O}_{2}$ (Xu et al., 2008). Recently, treatment with atorvastatin, SIM, and pravastatin augmented Bcl-2 protein levels and decreased markers of apoptosis in different cell types such as mesenchymal stem cells (Dong et al., 2011), human osteosarcoma cells (Zhao et al., 2012), and human atrial trabeculae (Lemoine et al., 2012), respectively. Although it is controversial whether Bcl-2 levels are decreased or increased by statins, such effects are dependent on statin concentrations (Johnson-Anuna et al., 2007; Zhao et al., 2012) and cell type as neoplastic cells may react differently to statins compared to normal cells (Spampanato et al., 2012). Much remained to find out how the concentration of statins is a critical factor influencing the cellular death/survival pathways in vivo.

Presumably, present data revealed that SIM and RST possess protective activity against cisplatin-induced nephrotoxicity via anti-inflammatory and anti-apoptotic mechanisms that reduce inflammatory markers; MPO, cytokines; TNF- $\alpha$, Il- $1 \beta$, and Nf-kB with a subsequent shift in expression levels of Bax and Bcl-2 towards cell survival and nephroprotection. Those observations were further augmented by significant improvement in the histopathological picture of renal tissues treated with SIM, while mild improvement was observed in rosuvastatin-treated renal tissues compared to cisplatin.

Our data highlights that the protective effects of SIM and RST might be attributable to their anti-apoptotic and antiinflammatory effects along with their already proven antioxidant activity. In conclusion, the current study revealed that SIM and RST protected against cisplatin-induced nephrotoxicity as they managed to increase kidney weight and kidney relative index, improve renal dysfunction (serum creatinine, urea, and uric acid) and reduce renal tissue levels of MPO, TNF- $\alpha$, IL- $1 \beta$ and NF-kB. Alteration in the expressions of renal caspase-3, Bax 
and Bcl-2 proteins in glomerular and tubular epithelium by SIM and RST was also significant with improvement in the overall histopathological picture. Thus, the study suggests SIM and RST as potent nephroprotective agents via mechanisms expand beyond their antioxidant and vascular effects to include anti-inflammatory and anti-apoptotic properties.

\section{CONFLICT OF INTERESTS}

Declared None.

\section{FUNDING}

The authors have no support or funding to report.

\section{ACKNOWLEDGMENTS}

The authors are thankful to Prof. Adel Bekir, Department of Pathology, Faculty of Veterinary Medicine, Cairo University, Egypt, for the kind help in histopathology and immunohistochemistry.

\section{REFERENCES}

Akalin Ciftci G, Ertorun I, Akalin A, Alatas IO, Musmul A. The effects of atorvastatin on antioxidant/antiinflammatory properties of HDLs in hypercholesterolemics. Turk J Med Sci. 2015; 45(2):345-51.

Amirshahrokhi K, Khalili AR. Thalidomide ameliorates cisplatin-induced nephrotoxicity by inhibiting renal inflammation in an experimental model. Inflammation. 2015; 38(2):476-84.

An Y, Xin H, Yan W, Zhou X. Amelioration of cisplatin-induced nephrotoxicity by pravastatin in mice. Experimental and toxicologic pathology. Exp Toxicol Pathol. 2011; 63(3):215-9.

Antoine DJ, Srivastava A, Pirmohamed M, Park BK. Statins inhibit aminoglycoside accumulation and cytotoxicity to renal proximal tubule cells. Biochem Pharmacol. 2010; 79(4):647-54.

Arany I, Safirstein RL. Cisplatin nephrotoxicity. Semin Nephrol. 2003; 23(5):460-4.

Baliga R, Zhang Z, Baliga M, Ueda N, Shah SV. In vitro and in vivo evidence suggesting a role for iron in cisplatin-induced nephrotoxicity. Kidney Int. 1998; 53(2):394-401.

Bancroft J, Stevens A, Turner D. Theory and practice of histological techniques: Churchill Livingstone New York. the text. 1996:766.

Blanco-Colio LM, Tunon J, Martin-Ventura JL, Egido J. Antiinflammatory and immunomodulatory effects of statins. Kidney Int. 2003; 63(1):12-23.

Carleton HM, Drury RAB, Wallington EA, Cameron R. Carleton's Histological technique. 4th ed. Oxford University Press: London; 1967. ix, 432 p. p.

Cohen SM, Lippard SJ. Cisplatin: from DNA damage to cancer chemotherapy. Prog Nucleic Acid Res Mol Biol. 2001; 67:93-130.

Dashti-Khavidaki S, Moghaddas A, Heydari B, Khalili H, Lessan-Pezeshki M, Lessan-Pezeshki M. Statins against drug-induced nephrotoxicity. J Pharm Pharm Sci. 2013; 16(4):588-608.

Davignon J. Beneficial Cardiovascular Pleiotropic Effects of Statins. Circulation. 2004; 109(23 suppl 1):III-39-III-43.

Deng J, Kohda Y, Chiao H, Wang Y, Hu X, Hewitt SM, Miyaji T, McLeroy P, Nibhanupudy B, Li S, Star RA. Interleukin-10 inhibits ischemic and cisplatin-induced acute renal injury. Kidney Int. 2001; 60(6):2118-28.

Dong Q, Yang Y, Song L, Qian H, Xu Z. Atorvastatin prevents mesenchymal stem cells from hypoxia and serum-free injury through activating AMP-activated protein kinase. Int J Cardiol. 2011; 153(3):311-6.

Franke C, Noldner M, Abdel-Kader R, Johnson-Anuna LN, Gibson Wood W, Muller WE, Eckert GP. Bcl-2 upregulation and neuroprotection in guinea pig brain following chronic simvastatin treatment. Neurobiol Dis. 2007; 25(2):438-45.
Fujieda M, Morita T, Naruse K, Hayashi Y, Ishihara M, Yokoyama $\mathrm{T}$, Toma T, Ohta K, Wakiguchi $\mathrm{H}$. Effect of pravastatin on cisplatin-induced nephrotoxicity in rats. Hum Exp Toxicol. 2011; 30(7):603-15.

Haendeler J, Hoffmann J, Zeiher AM, Dimmeler S. Antioxidant effects of statins via S-nitrosylation and activation of thioredoxin in endothelial cells: a novel vasculoprotective function of statins. Circulation. 2004; 110(7):856-61.

Hanigan MH, Devarajan P. Cisplatin nephrotoxicity: molecular mechanisms. Cancer Ther. 2003; 1:47-61.

Iseri S, Ercan F, Gedik N, Yuksel M, Alican I. Simvastatin attenuates cisplatin-induced kidney and liver damage in rats. Toxicology. 2007; 230(2-3):256-64

Jabbari M, Rostami Z, Jenabi A, Zahedi-Shoolami L, Mooraki A. Simvastatin ameliorates gentamicin-induced renal injury in rats. Saudi J Kidney Dis Transpl. 2011; 22(6):1181.

Jiang M, Wei Q, Wang J, Du Q, Yu J, Zhang L, Dong Z. Regulation of PUMA-alpha by $\mathrm{p} 53$ in cisplatin-induced renal cell apoptosis. Oncogene. 2006; 25(29):4056-66.

Johnson-Anuna LN, Eckert GP, Franke C, Igbavboa U, Muller WE, Wood WG. Simvastatin protects neurons from cytotoxicity by upregulating Bcl-2 mRNA and protein. J Neurochem. 2007; 101(1):77-86.

Johnson-Anuna LN, Eckert GP, Keller JH, Igbavboa U, Franke C, Fechner T, Schubert-Zsilavecz M, Karas M, Walter E. Müller WE, Wood WG. Chronic administration of statins alters multiple gene expression patterns in mouse cerebral cortex. J Pharmacol Exp Ther. 2005; 312(2):78693.

Jones MM, Basinger MA, Beaty JA, Holscher MA. The relative nephrotoxicity of cisplatin, cis-[Pt(NH3)2(guanosine)2]2+, and the hydrolysis product of cisplatin in the rat. Cancer Chemother Pharmacol. 1991; 29(1):29-32.

Kaushal GP, Kaushal V, Hong X, Shah SV. Role and regulation of activation of caspases in cisplatin-induced injury to renal tubular epithelial cells. Kidney Int. 2001; 60(5):1726-36.

Khoshnoud MJ, Naji Abdeh Moghbel B, Geramizadeh B, Niknahad H. Effect of simvastatin on cisplatin-induced nephrotoxicity in male rats. Iran J Pharm Res. 2011; 7(3):165-73.

Kodama A, Watanabe H, Tanaka R, Kondo M, Chuang VT, Wu Q, Endo M, Ishima Y, Fukagawa M, Otagiri M, Maruyama T. Albumin fusion renders thioredoxin an effective anti-oxidative and anti-inflammatory agent for preventing cisplatin-induced nephrotoxicity. Biochim Biophys Acta. 2014; 1840(3):1152-62.

Kuhlmann MK, Burkhardt G, Kohler H. Insights into potential cellular mechanisms of cisplatin nephrotoxicity and their clinical application. Nephrol Dial Transplant. 1997; 12(12):2478-80.

Launay-Vacher V, Rey JB, Isnard-Bagnis C, Deray G, Daouphars M. Prevention of cisplatin nephrotoxicity: state of the art and recommendations from the European Society of Clinical Pharmacy Special Interest Group on Cancer Care. Cancer Chemother Pharmacol. 2008; 61(6):903-9.

Lee RH, Song JM, Park MY, Kang SK, Kim YK, Jung JS. Cisplatin-induced apoptosis by translocation of endogenous Bax in mouse collecting duct cells. Biochem Pharmacol. 2001; 62(8):1013-23.

Lemoine S, Allouche S, Coulbault L, Cornet V, Massetti M, Galera P, Gérard JL, Hanouz JL. Mechanisms involved in cardioprotective effects of pravastatin administered during reoxygenation in human myocardium in vitro. Anesthesiology. 2012; 116(4):824-33.

Lieberthal W, Triaca V, Levine J. Mechanisms of death induced by cisplatin in proximal tubular epithelial cells: apoptosis vs. necrosis. Am J Physiol. 1996; 270 (4 Pt 2): F700-8.

Liu H, Gu LB, Tu Y, Hu H, Huang YR, Sun W. Emodin ameliorates cisplatin-induced apoptosis of rat renal tubular cells in vitro by activating autophagy. Acta Pharmacologica Sinica. 2016; 37(2):235-45.

Livingston RB. Cisplatin in the treatment of solid tumors: effect of dose and schedule. J Natl Cancer Inst. 1989; 81(10):724-5.

Madhusudhana Rao A, Anand U, Anand CV. Myeloperoxidase in chronic kidney disease. Indian J Clin Biochem. 2011; 26(1):28-31. 
Maheshwari RA, Sailor GU, Patel L, Balaraman R. Amelioration of cisplatin-induced nephrotoxicity by statins. Indian J Pharmacol. 2013; 45(4):354-8.

Malik S, Sharma AK, Bharti S, Nepal S, Bhatia J, Nag TC, Narang R, Arya DS. In vivo cardioprotection by pitavastatin from ischemicreperfusion injury through suppression of IKK/NF-kappaB and upregulation of pAkt-e-NOS. J Cardiovasc Pharmacol. 2011; 58(2):199-206.

Mason RP, Walter MF, Jacob RF. Effects of HMG-CoA reductase inhibitors on endothelial function: role of microdomains and oxidative stress. Circulation. 2004; 109(21 Suppl 1): Ii34-41.

Miller RP, Tadagavadi RK, Ramesh G, Reeves WB. Mechanisms of Cisplatin Nephrotoxicity. Toxins. 2010; 2(11):2490-518.

Munford RS. Statins and the acute-phase response. N Engl J Med. 2001; 344(26):2016-8.

Nam HK, Lee SJ, Kim MH, Rho JH, Son YK, Lee SM, Kim SE, Kim KH, An WS. Rosuvastatin attenuates inflammation, apoptosis and fibrosis in a rat model of cyclosporine-induced nephropathy. Am J Nephrol. 2012; 37(1):7-15.

Ozkok A, Edelstein CL. Pathophysiology of cisplatin-induced acute kidney injury. Biomed Res Int. 2014; 2014:967826.

Pabla N, Dong Z. Cisplatin nephrotoxicity: Mechanisms and renoprotective strategies. Kidney Int. 2008; 73(9):994-1007.

Palipoch S, Punsawad C, Koomhin P, Suwannalert P. Hepatoprotective effect of curcumin and alpha-tocopherol against cisplatininduced oxidative stress. BMC Complement Altern Med. 2014; 14:111.

Pan H, Chen J, Shen K, Wang X, Wang P, Fu G, Meng H, Wang Y, Jin B. Mitochondrial modulation by Epigallocatechin 3-Gallate ameliorates cisplatin induced renal injury through decreasing oxidative/nitrative stress, inflammation and NF-kB in mice. PLoS One. 2015; 10(4):e0124775.

Patassini S, Giampa C, Martorana A, Bernardi G, Fusco FR. Effects of simvastatin on neuroprotection and modulation of Bcl-2 and BAX in the rat quinolinic acid model of Huntington's disease. Neurosci Lett. 2008; 448(1):166-9.

Podrez EA, Abu-Soud HM, Hazen SL. Myeloperoxidasegenerated oxidants and atherosclerosis. Free Radic Biol Med. 2000; 28(12):1717-25.

Qin W, Lu Y, Zhan C, Shen T, Dou L, Man Y, Wang S, Xiao C, Bian Y, Li J. Simvastatin suppresses apoptosis in vulnerable atherosclerotic plaques through regulating the expression of $\mathrm{p}(53), \mathrm{Bcl}-2$ and $\mathrm{Bcl}-\mathrm{xL}$. Cardiovasc Drugs Ther. 2012; 26(1):23-30.

Rajtik T, Carnicka S, Szobi A, Mesarosova L, Matus M, Svec $\mathrm{P}$, Ravingerová T, Adameová A. Pleiotropic effects of simvastatin are associated with mitigation of apoptotic component of cell death upon lethal myocardial reperfusion-induced injury. Physiol Res. 2012; 61 Suppl 2: S3341

Ramesh G, Reeves WB. Salicylate reduces cisplatin nephrotoxicity by inhibition of tumor necrosis factor-alpha. Kidney Int 2004; 65(2): 490-9.

Ramesh G, Reeves WB. TNF-alpha mediates chemokine and cytokine expression and renal injury in cisplatin nephrotoxicity. J Clin Invest. 2002; 110(6): 835-42.

Ray KK, Cannon CP. The potential relevance of the multiple lipid-independent (pleiotropic) effects of statins in the management of acute coronary syndromes. J Am Coll Cardiol. 2005; 46(8):1425-33.

Safirstein R, Winston J, Goldstein M, Moel D, Dikman S, Guttenplan J. Cisplatin Nephrotoxicity. Am J Kidney Dis. 1986; 8(5):356-67.

Salama AAA, Mostafa RE, Omara EA. Ameliorative effects of phosphodiesterase (PDE) inhibitors in potassium dichromate-induced acute renal failure in rats. Int J Pharm Sci Rev Res. 2016; 36(2):40-6.

Saleh S, El-Demerdash E. Protective effects of L-arginine against cisplatin-induced renal oxidative stress and toxicity: role of nitric oxide. Basic Clin Pharmacol Toxicol. 2005; 97(2):91-7.

Sheikh-Hamad D, Cacini W, Buckley AR, Isaac J, Truong LD, Tsao CC, Kishore BK. Cellular and molecular studies on cisplatin-induced apoptotic cell death in rat kidney. Arch Toxicol. 2004; 78(3):147-55.

Shimeda Y, Hirotani Y, Akimoto Y, Shindou K, Ijiri Y, Nishihori

T, Tanaka K. Protective effects of capsaicin against cisplatin-induced nephrotoxicity in rats. Biol Pharm Bull. 2005; 28(9):1635-8.

Shiraishi F, Curtis LM, Truong L, Poss K, Visner GA, Madsen K, Nick HS, Agarwal A. Heme oxygenase-1 gene ablation or expression modulates cisplatin-induced renal tubular apoptosis. Am J Physiol Renal Physiol. 2000; 278(5):F726-36.

Shishehbor MH, Brennan ML, Aviles RJ, Fu X, Penn MS, Sprecher DL, Hazen SL. Statins promote potent systemic antioxidant effects through specific inflammatory pathways. Circulation. 2003; 108(4):426-31.

Siddik ZH. Cisplatin: mode of cytotoxic action and molecular basis of resistance. Oncogene. 2003; 22(47):7265-79.

Song X-F, Ren H, Andreasen A, Thomsen JS, Zhai X-Y. Expression of Bcl-2 and Bax in Mouse Renal Tubules during Kidney Development. PLoS ONE. 2012; 7(2):e32771.

Spampanato C, De Maria S, Sarnataro M, Giordano E, Zanfardino M, Baiano S, Cartenì M, Morelli F. Simvastatin inhibits cancer cell growth by inducing apoptosis correlated to activation of Bax and downregulation of BCL-2 gene expression. Int J Oncol. 2012; 40(4):935-41.

Strasser A, O’Connor L, Dixit VM. Apoptosis signaling. Annu Rev Biochem. 2000; 69:217-45.

Takemoto M, Liao JK. Pleiotropic effects of 3-hydroxy-3methylglutaryl coenzyme a reductase inhibitors. Arterioscler Thromb Vasc Biol. 2001; 21(11):1712-9.

Tilyek A, Chai C, Hou X, Zhou B, Zhang C, Cao Z, Yu B. The protective effects of Ribes diacanthum Pall on cisplatin-induced nephrotoxicity in mice. J Ethnopharmacol. 2016; 178:297-306.

Vita JA, Brennan ML, Gokce N, Mann SA, Goormastic M, Shishehbor MH, Penn MS, Keaney JF Jr, Hazen SL. Serum myeloperoxidase levels independently predict endothelial dysfunction in humans. Circulation. 2004; 110(9):1134-9.

Wang D, Lippard SJ. Cellular processing of platinum anticancer drugs. Nat Rev Drug Discov. 2005; 4(4):307-20.

Wei Q, Dong G, Franklin J, Dong Z. The pathological role of Bax in cisplatin nephrotoxicity. Kidney Int. 2007; 72(1):53-62.

Xu SZ, Zhong W, Watson NM, Dickerson E, Wake JD, Lindow SW, Newton CJ, Atkin SL. Fluvastatin reduces oxidative damage in human vascular endothelial cells by upregulating Bcl-2. J Thromb Haemost. 2008; 6(4):692-700.

Yang C, Kaushal V, Shah SV, Kaushal GP. Mcl-1 is downregulated in cisplatin-induced apoptosis, and proteasome inhibitors restore Mcl-1 and promote survival in renal tubular epithelial cells. Am J Physiol Renal Physiol. 2007; 292(6): F1710-7.

Zhao XH, Xu ZR, Zhang Q, Yang YM. Simvastatin protects human osteosarcoma cells from oxidative stress-induced apoptosis through mitochondrial-mediated signaling. Mol Med Rep. 2012; 5(2):483-8.

How to cite this article:

Mostafa RE, Saleh DO, Mansour DF. Cisplatin-Induced Nephrotoxicity in Rats: Modulatory Role of Simvastatin and Rosuvastatin against Apoptosis and Inflammation. J App Pharm Sci, 2018; 8(04): 043-050. 